\title{
SOME INEQUALITIES ON THE INVERSE SUM INDEG COINDEX
}

\author{
B. Mitić, E. Milovanović, M. Matejić, I. Milovanović*
}

Abstract. Topological indices and coindices play an important role in mathematical chemistry. In this paper we establish some lower and upper bounds for the inverse sum indeg coindex in terms of different graph parameters associated with the structure of the graph. We also obtain relations between the inverse sum indeg coindex and some other indices and coindices.

Mathematics subject classification (2020): 05C50, 15A12.

Keywords and phrases: Topological indices and coindices, Zagreb indices, inverse degree index, inverse sum indeg coindex.

\section{REFERENCES}

[1] M. O. Albertson, The irregularity of graph, Ars Comb. 46 (1997) 2015-2025.

[2] A. Ali, M. Matejić, I. Milovanović, E. Milovanović, Some new upper bounds for the inverse sum indeg index of graphs, Electron J. Graph Theory Appl. 8 (1) (2020) 59-70.

[3] A. R. Ashrafi, T. Došlić, A. Hamzeh, The Zagreb coindices of graph operations, Discrete Appl. Math. 158 (2010) 1571-1578.

[4] K. C. Das, I. Gutman, Some properties of the second Zagreb index, MATCH Commun. Math. Comput. Chem. 52 (2004) 66-80.

[5] K. CH. DAS, Sharp bounds for the sum of the squares of the degrees of a graph, Kragujevac J. Math. 25 (2003) 32-49.

[6] N. DE, S. M. A. NAYEEM, A. PAL, The F-coindex of some graph operations, Springer Plus, 5 (2016) $\# 221$.

[7] T. DošLIĆ, Vertex-weighted Wiener polynomials for composite graphs, Ars Math. Contemp. 1 (2008) 66-80.

[8] C. S. EDWARDS, The largest vertex degree sum for a triangle in a graph, Bull. London Math. Soc. 9 (1977) 203-208.

[9] S. FAJTLOWICZ, On conjectures of Graffiti-II, Congr. Numer. 60 (1987) 187-197.

[10] F. Falahati-Nezhad, M. AZARI, T. DošLić, Sharp bounds on the inverse sum indeg index, Discrete Appl. Math. 217 (2017) 185-195.

[11] G. H. FATH-TABAR, Old and new Zagreb indices of graphs, MATCH Commun. Math. Comput. Chem. 65 (2011) 79-84.

[12] B. Furtula, I. Gutman, A forgotten topological index, J. Math. Chem. 53 (4) (2015) 1184-1190.

[13] B. Furtula, I. Gutman, Ž. Kovijanić Vukičević, G. Lekishvili, G. Popivoda, On an old/new degree-based topological index, Bull. Acad. Serbe Sci. Arts (Cl. Sci. Math. Natur.) 40 (2015) $19-31$.

[14] A. Ghalavand, A. Ashrafi, I. Gutman, New upper and lower bounds for some degree-based graph invariants, Kragujevac J. Math. 44 (2) (2020) 181-188.

[15] I. GutMan, N. TRINAJSTIĆ, Graph theory and molecular orbitals. Total $\pi$-electron energy of alternant hydrocarbons, Chem. Phys. Lett. 17 (1972) 535-538.

[16] I. Gutman, B. Ruščić, N. TRinajstić, C. F. WilcoX, Graph theory and molecular orbitals. XII. Acyclic polyens, J. Chem. Phys. 62 (1975) 3399-3405.

[17] I. Gutman, On the origin of two degree-based topological indices, Bul. Acad. Serbe Sci. Arts. (Cl. Sci Math. Natur) 146 (2014) 39-52. 
[18] I. Gutman, M. Matejić, E. Milovanović, I. Milovanović, Lower bounds for inverse sum indeg index of graphs, Kragujevac J. Math. 44 (4) (2020) 551-562.

[19] I. Gutman, On coindices of graphs and their complements, Appl. Math. Comput. 305 (2017) 161165.

[20] I. Gutman, B. Furtula, Ž. Kovijanić Vukičević, G. Popivoda, On Zagreb indices and coindices, MATCH Commun. Math. Comput. Chem. 74 (2015) 5-16.

[21] I. Gutman, J. M. Rodriguez, J. M. SigarReta, Linear and non-linear inequalities on the inverse sum indeg index, Disrete Appl. Math. 258 (2019) 123-134.

[22] I. Gutman, P. Hansen, H. MÉLOt, Variable neighborhood search for extremal graphs 10. Comparison of irregularity indices for chemical trees, J. Chem. Inf. Model. 45 (2005) 222-230.

[23] P. HANSEn, H. MÉLOT, Variable neighborhood search for extremal graphs 9. Bounding the irregularity of a graph, in: S. Fajtlowicz, P. W. Fowler, P. Hansen, M. F. Janowitz, F. S. Roberts (Eds.), Graphs and Discovery, Am. Math. Soc., Providence, 2005, pp. 253-264.

[24] A. ILIĆ, D. Stevanović, On computing Zagreb indices, MATCH Commun. Math. Comput. Chem. 62 (2009) 681-687.

[25] T. MAnsour, C. Song, The $a$ and $(a, b)$-analogs of Zagreb indices and coindices of graphs, Int. J. Comb. 2012 (2012) Art. ID 909285.

[26] M. M. MatejIĆ, I. Ž. Milovanović, E. I. Milovanović, Upper bounds for the inverse sum indeg index of graphs, Discrete Appl. Math. 251 (2018) 258-267.

[27] E. I. Milovanović, I. Ž. Milovanović, Sharp bounds for the first Zagreb index and first Zagreb coindex, Miskolc Math. Notes, 16 (2) (2015) 1017-1024.

[28] D. S. Mitrinović, P. M. Vasić, Analytic inequalities, Springer Verlag, Berlin-Heidelberg-New York, 1970.

[29] S. Nikolić, G. KovačEvić, A. Milićević, N. Trinajstić, The Zagreb indices 30 years after, Croat. Chem. Acta 76 (2003) 113-124.

[30] J. RADON, Theoretic and Anwendungen der absolut additiven Mengenfunktionen, Sitzunhgsber. Acad. Wissen. 122 (1913), 1295-1438.

[31] B. C. RenNiE, On a class of inequalities, J. Austr. Math. Soc. 3 (1963) 442-448.

[32] J. Sedlar, D. Stevanović, A. Vasilyev, On the inverse sum indeg index, Discrete Appl. Math. 184 (2015) 202-212.

[33] R. Todeschini, V. Consonni, Handbook of Molecular descriptors, Wiley-VCH, Weinheim, 2000.

[34] R. Todeschini, V. Consonni, Molecular descriptors for chemoinformatics, Wiley-VCH, Weinheim, 2009.

[35] M. Veylaki, M. J. Nikmehr, H. A. Tavallare, The third and hyper-Zagreb coindices of some graph operations, J. Appl. Math. Comput. 50 (2016) 315-325.

[36] D. VuKIČEVIĆ, Bond additive modeling 2. Mathematical properties of max-min rodeg index, Croat. Chem. Acta 83 (3) (2010) 261-273.

[37] D. Vukičević, M. Gašperov, Bond additive modeling I. Adriatic indices, Croat. Chem. Acta 83 (3) (2010) 243-260.

[38] K. XU, K. CH. DAs, K. TANG, On the multiplicative Zagreb coindex of graphs, Opuscula Math. 33 (1) (2013) 197-210.

[39] Y. S. Yoon, J. K. KIM, A relationship between bounds on the sum of squares of degrees of a graph, J. Appl. Math. Comput, 21 (2006) 233-238.

[40] S. H. Zadeh, A. Hamzeh, A. R. Ashrafi, Extremal properties of Zagreb coindices and degree distance of graphs, Miskolc Math. Notes 11 (2) (2010) 129-137. 